\title{
PROSES DAN PERAN KOMUNIKASI DALAM MENGATASI QULTURE SHOCK (STUDI KASUS PADA MAHASISWA UNIVERSITAS TADULAKO)
}

\author{
Dwi Rohma Wulandari \\ Universitas Tadulako \\ rohma@untad.ac.id
}

\begin{abstract}
Abstrak
Dalam penelitian ini akan menjelaskan bentuk gegar budaya dan peran serta proses komunikasi yang dilakukan dalam mengatasi gegar budaya yang ada. Objek kajian yang dilakukan adalah fenomena gegar budaya yang terjadi pada mahasiswa asing di Universitas Tadulako. Teori akomodasi dimanfaatkan sebagai ladasan berpikir dalam penelitian ini. Metode studi kasus dalam menganalisis hasil penelitian. Hasil dari penelitian ini memperlihatkan bahwa empat fase dalam gegar budaya memperlihatkan perbedaan yang terlihat dimana ada euphoria dan antusias dalam menyambut kehidupan baru dengan budaya baru. Penggunaan aksen dan pengucapan dengan intonasi yang berbeda menjadi kendala kultur yang tetap ada Ketika memasuki lingkungan baru. Proses adabtasi tidak memerlukan waktu lama Ketika mahasiswa asing Universitas Tadulako berada pada recovery phase sudah mampu menerima perbedaan dengan interaksi yang rutin dan proses komunikasi dilakukan secara efektif. Untuk memahami nilai budaya, keterampilan masing-masing individu menjadi penting, karena dengan keterampilan berkomunikasi akan menjadikan proses adabtasi, memahami budaya, dan akan mengurangi atau meminimalisir terjadinya culture shock. Proses sosialisasi dengan pola nilai budaya dapat digunakan untuk menghindari adanya gegar budaya.
\end{abstract}

Kata Kunci: Fenomena budaya, Gegar budaya, Interaksi, Komunikasi, Nilai budaya

\begin{abstract}
This research explain the form of culture shock and the role and process of communication in overcoming the existing cultural shock. The object of the study is the phenomenon of culture shock that occurs in foreign students at Tadulako University. Accommodation theory is used as a basis for thinking in this study. Case study method in analyzing existing research results. The results of this study indicate that the four phases in a culture shock show a visible difference where there are euphoria and enthusiasm in welcoming a new life with a new culture. The use of accents and pronunciations with different intonations becomes a cultural obstacle that remains when entering a new environment. The adaptation
\end{abstract}


process does not take long. When foreign students of Tadulako University are in the recovery phase, they are able to accept differences with routine interactions, and the communication process is carried out effectively. To understand cultural values, the skills of each individual are important, because communication skills will make the process of adaptation, understanding culture, and will minimize the occurrence of culture shock. The socialization process with a cultural value pattern can be used to avoid cultural shocks.

Keywords Communication, Cultural shock, Cultural values, Cultural phenomena, Interaction

\section{Pendahuluan}

Komunikasi yang efektif akan terjadi apabila terjadi Kerjasama dan interaksi yang baik dengan orang lain. Kegiatan dari interaksi ini bisa menjadi sebuh proses komunikasi didalamnya, sehingga terjadi kesepahaman makna dan tujuan yang sama. Budaya mampu menjadi penjembatan dalam berkomunikasi, dua budaya yang sama maka akan menghasilkan makna dan pengertian yang sama Ketika berkomunikasi. Berbeda Ketika berkomunikasi dengan budaya yang berbeda, maka akan timbul cultural shock/problems yang akan membatasi proses komunikasi.

Keterkaitan yang ada pada budaya serta komunikasi berada pada sikap manusia dan proses dalam memenuhi kebutuhan interaksi dan kebutuhan kepuasan ketika berkomunikasi dengan orang lain. Hubungan sosial akan terjadi dengan adanya proses interaksi ini, pesan dan informasi yang disampaikan melalui perilaku manusia menjadikan praktik-praktik komunikasi yang beragam. Budaya menjadi sebuah "programming of mind" karena interaksi yang terjadi akan membentuk sebuah pola tertentu berdasarkan situasi dan kondisi seseorang pada saat berkomunikasi (Nasrullah Rulli, 2012:16).

M anusia mempelajari bahasa dari budaya yang berbeda dengan kebudayaan yang berbeda pula berdasarkan aksen dan dialek dari segi bahasa verbalnya saja. Akan tetapi, pada saat berkomunikasi manusia lebih banyak menggunakan 
bahasa nonverbal dari pada bahasa verbal. Kegiatan tersebut sejalan dengan keadaan dimana disaat secara mayoritas pada individu-individu yang tinggal dalam situasi yang sama, serta wilayah dengan nilai budaya yang ada sejak individu lahir. Secara alamiah proses itu dihadapi tanpa sadar maka setiap individu yang mereka temui akan memiliki nilai yang sama pula sehingga cultural value yang ada tidak akan hilang ataupun menjadikan itu sebagai hambatan dalam proses interaksi maupun komunikasi pada aktivitas kesehatian mereka.

Masa dimana manusia mengalami situasi dunia baru dengan sendirinya segala bentuk interaksi yang terjadi akan terasa asing, maka akan terlihat rasa cemas dan nyaman pun hilang. Kecemasan terbesar yang akan selalu muncul yakni proses interaksi dan adabtasi yang memerlukan berkomunikasi. Ketika kita berkomunikasi dengan seseorang dengan nilai budaya serupa, maka proses berkomunikasi akan lebih natural atau mudah di akomodasi dan ditampilkan, karena dalam suatu budaya yang sama individu akan berbagi sejumlah pengalaman serupa. Namun bila prose berkomunikasi melibatkan individu berbeda nilai serta budaya, maka pengalaman berbeda secara sadar terjadi dan proses komunikasi juga akan terhalang. Sesuatu yang sangat alamiah Ketika individu mengalami berbagai macam persoalan ketika berada pada situasi dan kondisi dengan nilai budaya yang berbeda yang akan berdampak pada sisi fisik dan sisi psikis individu.

Berdasarkan fenomena culture shock atau gegar budaya, hal ini sejalan dengan hasil pengembangan penelitian konsep gegar budaya yang terjadi. Terdapat tiga hal yang akan dianggap sebagai persoalan yang penting dalam gegar budaya ini yaitu, kendala Bahasa, perbedaan makna dan simbol, kesulitan yang di alami akan menjadi persoalan ketika akan berinteraksi dalam aktivitas sehari-hari. Perbedaan nilai yang dianut karena perbedan budaya yang sangat mendasar. Nilai dalam proses berinteraksi menjadi sebuah ideologi dalam berbudaya, dan ideologi menjadi sebuah ketetapan dan cara yang sudah melekat pada setiap individu berdasarkan latar belakang kehidupan sebagai bagian dari 
masyarakat dan proses kehidupan sosialnya. Serta pola perilaku budaya yang juga berbeda, perilaku budaya terlihat dalam bentuk sikap dan tindakan yang dilakukan setiap hari. Permasalahan ini sering muncul Ketika kurangnya pemahaman dan proses transmisi informasi yang dilakukan saat berkomunikasi (Hadawiah, 2019).

Proses penyesuaian diri tidak lagi menjadi proses bertahan hidup dalam lingkungan sosial Ketika terjadi gegar budaya. Lost control secara otomatis akan terjadi pada individu-individu disaat berada pada lingkungan ataupun kondisi yang asing dan belum dipahami secara budaya akan membentuk dan menghasilkan tanda gegar budaya pada individu tersebut. (Roger \& Steinfatt dalam Kusherdyana, 2011 : 74). Sebagai penawar untuk memberikan stimuli dan meminimalisir gegar budaya yang terjadi maka peran yang ada berada pada proses komunikasi yang melibatkan budaya itu sendiri (Mulyana dan Rakhmat, 2010:174). Fenomena gegar budaya ini sering sekali ditemukan di Indonesia, khususnya dalam dunia pendidikan. Indonesia sering didatangi oleh para mahasiswa asing dengan tujuan untuk menuntut ilmu. Hal ini terjadi dikarenakan program pemerintah maupun program dari Universitas yang ada di Indonesia yang biasa disebut dengan pertukaran pelajar, dalam hal ini, terjadi pertukaran pesan dari kebudayaan yang berbeda. Dimana, komunikasi lintas budaya sendiri merupakan proses komunikasi yang terjadi antara dua orang atau lebih yang memiliki kebudayaan berbeda atau berasal dari wilayah yang berbeda.

Proses berinteraksi dan berkomunikasi tersebut terjadi saling pengaruhmempengaruhi antara kedua belah pihak. Fenomena global saat ini sedang berlangsung interaksi dalam lingkungan kita, yang memaksa kita untuk memperhatikan budaya yang baru. Tersebarnya suatu kebudayaan atau masuknya unsur budaya Indonesia ke dalam mahasiswa asing melalui interaksi sosial, yaitu bentuk kongkrit dari interaksi tersebut adalah komunikasi, karena masing-masing dari mereka mempunyai budaya, sehingga interaksi yang berlangsung mengakibatkan saling transfer budaya, pada saat berkomunikasi 
antara mahasiswa asing dan mahasiswa Universitas Tadulako sering mengalami perbedaan dalam bahasa (aspek verbal dan non verbal), persepsi, sikap, kebiasaan, nilai-nilai, gaya hidup (life style), maupun pola berpikir.

Kesalahpahaman dalam berkomunikasi yang sering terjadi antara mahasiswa asing dengan mahasiswa Universitas Tadulako yang memiliki latar belakang yang berbeda dengan negara asal mereka. Ketika mahasiswa-mahasiswi dari budaya yang berlainan berkomunikasi, sering terjadi mis communication dan keliru dalam hal penafsiran adalah hal yang biasa ditemui, melalui komunikasi lintas budaya yang bisa terjadi dalam konteks komunikasi manapun. Dari praobservasi yang terjadi, disaat mahasiswa asing asal Thailand Angkatan 2015 melakukan proses komunikasi, ada perbedaan dialek, ekspresi yang ditunjukkan serta kebiasaan yang jauh berbeda Ketika pertama ikut dalam kegiatan pengenalan situasi yang ada di Universitas, proses yang terjadi Ketika berlangsung ada seorang senior yang meneriaki mereka dengan nada yang keras disaat ingin menegur, hal tersebut memberikan ekspektasi dan kesan yang negatife untuk pertama kali. Sementara kultur budaya timur, berbicara dengan intonasi yang tinggi adalah hal biasa, seperti hal saling menyapa.

Proses komunikasi merupakan hal yang sangat penting untuk dijalani oleh para mahasiswa asing di manapun mereka berada baik di lingkungan kampus, tempat tinggal, tempat wisata, pasar, dan lain-lain. Pada kajian komunikasi antarbudaya, proses komunikasi salah satunya bertujuan untuk mengurangi tingkat ketidakpastian (Liliweri, 2011). Pengurangan ketidakpastian yang terjadi di antara para mahasiswa asing ketika mereka mulai membuka diri untuk mengenal orang lain, baik sesama mahasiswa asing maupun dengan mahasiswa lokal di Universitas Tadulako dan masyarakat yang ada di Kota Palu. Jalinan komunikasi dan interaksi tersebut akan membuka informasi dan kemungkinan perkembangan hubungan yang lebih jauh yang membuat mereka semakin mudah untuk memprediksi pola dan bentuk komunikasi lebih lanjut. 
Berdasarkan analisis (Hadawiah, 2019) Proses interaksi yang terjadi pada mahasiswa perantauan dari luar daerah yang berbeda budaya melibatkan fase awal resolusi dalam gegar budaya yakni kekecewaan, kesenjangan dan perbedaan budaya yang ada menjadikan proses adaptasi Kembali untuk memulai interaksi dan proses komunikasi yang menimbulkan pertukaran pada perbedaan makna, persepsi dan perspektif. Penelitian yang sama juga pernah dilakukan, sebagaimana yang diungkapkan Abbasian \& Sharifi (2013:154-159) pengalaman menjadi kejutan budaya bagi mahasiswa asing yang tinggal di daerah Persia, selain faktor lingkungan, proses sosioloinguistik sangat berperan dalam proses terjadinya komunikasi, dengan mengumpulkan berbagai pengalaman secara kognitif menjadikan hal tersebut masalah yang sangat besar maka terjadi gegar budaya di dalamnya. Hal mendasar yang menjadi kebaharuan dalam penelitian ini yang di kaji dengan memanfaatkan teori akomodasi dan tahapannya dalam proses komunikasi mampu dijelaskan dalam fase akomodasi agar menghasilkan komunikasi efektif dan tidak hanya melihat pada persoalan yang menyebabkan culture shock terjadi.

\section{Tujuan Penelitian}

Penelitian ini dilakukan untuk menjelaskan dan lebih memahami bentuk gegar budaya yang dialami pada mahasiswa di lingkungan Universitas Tadulako, serta bagaimana proses komunikasi berperan dalam melakukan proses interaksi untuk mengatasi gegar budaya yang terjadi.

\section{Kerangka Teori}

Proses akomodasi yang dilakukan baik secara konvergensi ataupun divergensi lebih cenderung terjadi Ketika individu berada pada alam bawah sadarnya sendiri, perilaku ini dilakukan melalui intonasi suara, kecepatan berbicara, aksen, volume suara lawan bicara, tata bahasa dan gerak tubuh. Dalam komunikasi hal yang lebih menekankan proses identitas sosial yang ada yakni akomodasi namun 
sebaliknya dapat pula membuat sebuah perbedaan dan jarak yang kuat pula dalam prosesnya. Sebagai contoh, disaat seseorang ingin melakukan konfirmasi terhaap orang lain maka aka terjadi proses koncergensi. Proses tersebut juga dapat terulang Ketika bertemu kelompok maupu individu yang memiliki kesamaa serupa. Persamaan yang kuat antar individu akan memungkinkan terjalinnya hubungan yang baik (M orissan, 2013: 212).

Komunikasi menciptakan suatu jaringan hubungan-hubungan diantara orang yang terdiri dari struktur masyarakat. Jaringan menghubungkan kelompokkelompok satu sama lainnya dan memungkinkan mereka untuk bertukar informasi dan kelompok-kelompok berkumpul bersama berdasarkan pada nilai, perilaku, kepercayaan yang sama. Teori konvergensi menjelaskan mengapa ada perbedaan dalam kelompok-kelompok dan perbedaan diantara mereka. Hal inilah yang menjadikan peran komunikasi dapat mengatasi gegar budaya.

Pada komunikasi antarbudaya lebih melihat pada perspektif dengan tujuan komunikasi antarbudaya lebih meminimalisir ketiakastian yang terjadi terhadap orang lain (Liliweri, 2011:19). Dalam perspektif tersebut dijelaskan terkait komunikasi mampu meminimalisir rasa ketidakpastian Ketika mahasiswa asing mulai berinteraksi dengan mahasiswa lokal lainnya. Uraian Berger dan Calabrese mengemukakan bahwa seseorang mampu memprediksi ketidakpastian pada perjumpaan awal, maka akan mampu mengurasi rasa kecemasan dan menciptakan situasi yang baik sebagai awal dalam menjalin proses komunikasi interpersonal. Bentuk komunikasi antarbudaya yang dialami oleh mahasiswa asing ketika mereka memasuki lingkungan yang baru dan bertemu dengan mahasiswa Universitas Tadulako yang berbeda budaya dengan mereka. M enurut Samovar, Porter dan Mc. Daniel, 2007:336 terdapat empat bentuk tingkatan gegar budaya yaitu: Optimistic Phase, Cultural Problems, Recovery Phase, dan Adjustment Phase.

Berdasarkan empat bentuk tingkatan gegar budaya tersebut peneliti ingin melihat pada fase yang mana yang paling berpengaruh dalam hal ini 
komunikasi yang ada pada komunikasi antarbudaya berperan sebagai jenis komunikasi yang memiliki peran sangat efektif sebagai wadah dan proses meminimalisir cultural shock yang dialami oleh mahasiswa asing di Universitas Tadulako. Keempat fase gegar budaya tersebut pasti membutuhkan waktu dan usaha dari masing-masing individu untuk menanggulanginya, agar setiap individu mampu mendapatkan penggambaran dan mampu memahami bahwa aktivitas komunikasi antarbudaya mempunyai peran untuk mengatasi fenomena gegar budaya agar mahasiswa asing mampu menyesuaikan diri dengan situasi dan kondisi yang ada pada lingkungan baru. Accommodation theory dalam penelitian ini digunakan mengakomodir pada proses komuniasi seorang komunikator, mengambil tindakan selanjutnya pada komunikan serta mampu beradaptasi dengan lingkungan dengan mengandalkan motivasi dari setiap individu (Yohana \& Yozani: 2017:95-106).

\section{Metode Penelitian}

Metode yang digunakan untuk penyelesaian penelitian yakni studi kasus dengan riset yang mampu menjelaskan dan menguraikan Mulyana (2007:201), dengan instrumen menggunakan data dan informasi dalam pengumpulan data berupa indept interview serta dokumentasi. Bentuk analisis data dilakukan dengan analisis model interaktif (Interactive Model Of Analisis) yakni reduksi data serta data display (Emzir, 2010).

\section{Hasil Penelitian dan Pembahasan}

Fase optimistik memberikan tahapan berupa rasa kegembiraan, harapan, dan euforia yang menjadi Langkah untuk meminimalisir individu ketika memasuki budaya baru sebelum gegar budaya tersebut terjadi. Walaupun fenomena culturak shock ini masih akan selalu berproses sampai pada masaing-masing individu mampu memahami lingkungannya. Peristiwa yang sering terjadi kemudian Ketika masa-masa tersebut menimbulkan motivasi lain yang di rasakan 
oleh mahasiswa asing tersebut karena memasuki lingkungan dan dunia baru yang diawal sudah diakomodir melalui program beasiwa. Akan tertapi kemudia para mahasiswa asing tiak memanfaatkan proses ini untuk mendapatkan informasi sebanyak mungkin terkiat lingkungan baru tersebut terkhusus di Indonesia, Palu, dan Universitas Tadulako.

Disaat cultural shock terjadi pada individu, bisa berdampak baik dan buruk kepada individu itu sendiri. Karena hasil dari interaksi yang ditimbulkan dari gegar budaya yang akan dialami setiap individu berbeda-beda. Ketika mahasiswa asing tersebut mampu beradaptasi engan baik dengan situasi serta kondisi baru di lingkunggannya maka akan menghasilkan sesuatu yang baik dalam diri individunya. Namun begitu berbagai persoalan mulai terjadi dan inividu tersebut tidak mampu mengakomodir hal tersebut seperti sulit memahami bahasa, dialek dan intonasi yang ada di lingkungan barunya, maka fase dimana seorang akan mengalami perasaan yang ditandai dengan kegeisahan akan sesuatu, kecewa dengan diri sendiri, dimana pada fase ini mampu menimbulkan hal-ha yang tidak seharusnya terhadap individu tersebut.

Perasaan homesick seringkali membuat gelisah bagi orang-orang yang jauh dari keluarga/orang tua, apalagi saat mereka tidak bisa pulang ke negaranya. Tapi sekarang, rasa rindu sudah bisa terobati dengan adanya kemajuan teknologi dan informasi seperti, telepon genggam dan media sosial yang memungkinkan orang-orang dapat saling berhubungan sehingga mereka juga bisa menelfon orangtua atau saudara, dan bisa menceritakan aktivitas mereka sehari-hari. Jika hal ini mereka lakukan, perlahan-lahan perasaan homesick yang mereka rasakan tidak membuat mereka gelisah lagi dan rasa rindu pada rumah pun perlahan akan terobati.

Fase masalah kultural (cultural problems/ culture shock). Fase yang menunjukkan persoalan mulai terlihat dan berkembang, sebagai mana yang dialami para mahasiswa asing, kurangnya pemahaman Bahasa dalam melakukan komunikasi, mengenal lingkungan barunya. Banyak terdapat perbedaan 
beragama/kepercayaan yang di anut, banyak tempat ibadah seperti mesjid, banyak perempuan berjilbab atau banyak mayoritas muslim, tradisi hari raya, menjadi hal utama yang diingat oleh para mahasiswa asing ketika bercerita tentang spiritualitas. Dengan tata cara beribadah yang berbeda. Akan tetapi persolan tersebut tidak menjadi kendala dan menggangu para mahasiswa asing.

Sebagaimana yang diungkapan (Lewis \& Slade dalam Rahardjo, 2005:54) kendala yang akan muncul Ketika terjadi pertukarn budaya yakni perilaku kultural, bahas serta nilai yang dianut masing-masing budaya. Hal tersebut bisa menjadi landasan dan informasi awal yang dapat digunakan untuk meningkatkan eksistensi diri individu dalam hal memotivas mereka untuk mampu berinteraksi dengan mahasiswa lokal lainnya dan mampu bekerja sama dalam rangka menjalani kegiatan dan kehidupan akademik kampus, dan bisa dilakukan secara perlahan-lahan sebagai sebuah proses untuk memahami nilai kultural yang ada di lingkungan baru mereka.

Kebiasaan menggunakan bahasa dari negaranya seringkali menjadi salah satu faktor yang menjadi identitas tersendiri bagi mahasiswa asing khususnya dari luar negeri yang identik dengan aksen asing yang cukup kuat, memberikan perbedaan yang cukup besar saat mereka menggunakan aksen asing ataupun aksen mereka saat berbicara dengan mahasiswa di untad yang berbeda budaya dengan mereka. Ini terlihat dari cara mereka memulai berinteraksi dengan lingkungan mereka yang baru. Interaksi yang dilakukan mulai dari memperhatikan, mempelajari kemudian diprektekkan dilingkungan baru.

Persoalan lain yang muncu sebagai akibat dari cultural shock adalah persoalan-persoalan lokal yang terjadi pada mahasiswa di Universitas Tadulako, dimana dalam kegiatan keseharian Ketika berkomunikasi dengan masing-masing individu dan kelompok, hanya menggunakan Bahasa lokal / daerah, walaupun pada saat berkomunikasi mereka menggunakan Bahasa Indonesia sebagai pengantar, akan tetapi ada dialek dan intonasi yang hanya memanfaatkan Bahasa daerah mereka. Dalam hal ini prose eksistensi Bahasa yang digunakan 
bisa menjadi persoalan mendasar sehingga menurunkan Kembali motivasi mahasiswa asing untuk mau berkomunikasi lebih lanjut. Proses gegar budaya ini akan berlanjut Ketika motivasi tersebut tidak mampu di atasi dengan proses adaptasi yang baik dengan lingkungannya.

Perbedaan bahasa sering kali membuat para mahasiswa asing salah paham, tidak mengerti bahkan bingung dengan bahasa yang sering digunakan dengan teman-teman mereka yang ada utamanya di lingkungan kampus. Begitupun sebaliknya kadang tidak memahami dengan baik apa yang di katakan oleh para mahasiswa asing. Interaksi antar mahasiswa terutama yang memiliki perbedaan budaya dan bahasa kurang aktif dalam berkomunikasi. Dari hasi pengamatan yang ada, mahasiswa asing lebih aktif berkomunikasi dengan sesama negara mereka, seperti mahasiswa Thailand, Vietnam dan beberapa dari beberapa negara lain. Interaksi antar mereka bersifat statis dimana mereka tetap menggunakan bahasa mereka ketika berkomunikasi dan bercanda dengan teman-teman dari sesama negara mereka maupun dari negara lain dan dari mahasiswa lokal Universitas Tadulako, sehingga terkadang menimbulkan kesalahpahaman dan tidak tercapainya tujuan komunikasi antar mereka.

Perubahan dan penyesuaian diri terhadap lingkungan budaya yang baru dapat membuat individu tidak dapat berinteraksi secara efektif di dalam lingkungan yang baru. Orang tersebut merasa dirinya berada di lingkungan yang asing. Sehingga ada perasaan was-was dan ketakutan dalam dirinya. Apalagi di tambah dengan kemampuan berkomunikasi yang kurang efektif. Sejalan dengan hasil penelitian yang diungkapan (0.Rikastana,2015), proses akomodasi membantu individu Ketika perilaku mereka ingin terlihat sama dengan orang disekitarnya, Ketika mendapatkan masalah dalam interaksi mana mereka melakukan pembukaan diri sebagai alternatif mengurangi mis komunikasi yang terjadi.

Kondisi lingkungan akan menjadi suatu hal yang dapat menyebabkan gegar budaya, karena sangat berbeda dengan kondisi cuaca yang ada di negara 
mahasiswa asing. Perilaku kita Ketika berkomunikasi berkomunikasi lebih banyak di pengaruhi kultur kebudayaan yang sifatnya lokal, perlu adanya perhatian yang lebih agar proses yang menghamat interkasi ini lebih berkurang. Justru seharusnya sumber digunakan serta di manfaatkan sebaik mungkin untuk memperkaya pengalaman komunikasi sebagai individu. Ketika ingin menciptakan komunikasi menjadi lebih efektif, perlu adanya proses saling menghargai dalam perbedaan yang ada. Karena proses penyesuaian dan adaptasi yang akan dilakukan tidka semudah ekspektasi awal Ketika motivasi itu mulai terhambat kemudian.

Recovery Phase, pada fase ini mahasiswa asing tidak memerlukan waktu yang begitu lama untuk lebih mengerti dan memahami segala situais dan kondisi dengan budaya baru di lingkungannya. Karena pada fase ini berlangsung proses interaksi yang dilakukan secara berkala dan komunikasi yang tidak terputus sebagai bagian keseharian mereka Ketika bertemu masyarakat ataupun mahasiswa lokal yang ada. Ada beberapa aspek yang membantu menjalankan proses pengertian dan pemahaman ini, diantaranya motivasi, pengalaman yang terjadi terus-menerus sebagai bahan pembelajaran, individu dengan karakteristik mudah bergaul dengan orang lain, dan proses komunikasi yang terjalin baik dalam bentuk verbal ataupun non verbal dengan mahasiswa laiinya dalam lingkup Univeristas.

Ketika mahasiswa asing berinteraksi dengan mahasiswa lokal laiinya maka secara tidak langusng mereka akan mengalami pengenalan budaya baru dari tiap individu yang mereka jumpai. Dan proses berkomunikasi secara alamiah akan terus terjadi. Walaupun dalam kegiatan yang terjadi proses tersebut banyak mengalami hambatan dalam konteks mengerti secara langsung maksud informasi dari interaksi yang ada. Tidak jarang perlu melakukan pengulangan yang ditekannkan dengan proses komunikasi non verbal yang mampu di pahami mahasiswa asing. 
Perbedaan culture juga mempengaruhi kepribadian mahasiswa asing. Adjustment Phase, pada proses ini menjadi fase terakhir dimana individu mengerti dan memahami elemen-elemen kunci dari budaya barunya (nilai-nilai, pola komunikasi, keyakinan, dan lain-lain). Kemampuan untuk hidup dalam dua budaya yang berbeda. Biasanya juga disertai dengan rasa puas. mereka sudah mampu beradaptasi, walalupun ketika awal mereka tiba dilingkungan yang berbeda dengan perasaan yang kurang nyaman dan sedikit stress, namun seiring dengan berjalannya waktu dan keinginan mereka juga sangat besar untuk berusaha dan mau belajar, membuat mereka mampu beradaptasi dengan lingkungan yang baru, para mahasiswa asing dapat merasa senang. Di saat mahasiswa asing memasui lingkungan baru secara otomatis akan mengalami kontak budaya. Dan komunikasi antar dua budaya berbeda akan terjadi dalam proses interaksi tersebut. Hal ini akan sejalan dengan motivasi sera usaha yang dilakukan mahasiswa asing Ketika berada pada lingkungan dengan budaya berbeda dalam memaknai informasi maupun pesan yang mereka terima sebagai bentuk respon yang ditandai adanya proses komunikasi didalamnya antar individu ataupun kelompok.

Proses komunikasi berperan saat para mahasiswa asing sudah mempunyai pemahaman tentang kebutuhna dirinya sebagai individu saat ingin berinteraksi maupun berkomunikasi. Prose belajr dan motivasi bertahan hidup sebagai bagian dari proses adaptasi menjadi penting Ketika menjalankan komunikasi antar budaya berbeda. Di beberapa sesi dilakukan Ketika mahsiswa asing mauun mahaiswa lokal berinteraksi, mereka akan berbagai pengalamn dan pengetahuan terait budaya mereka masing-masing, sebagai prose pertukaran nilai budaya. Dan hal ini sangat membatu dari proses mahasiswa asing menjalai aktivitasnya di lingkungan Universitas Tadulako khususnya kota palu sebagai kota yang baru mereka ketahui untuk menyelesaikan proses Pendidikan, dan menjalani proses akademik laiinya. 
Di samping komunikasi antarbudaya, komunikasi kelompok, massa, dan budaya juga memainkan peran dalam proses adaptasi dan penyesuaian diri para mahasiswa asing dengan lingkungan barunya. Komunikasi budaya atau komunikasi kultural berperan dalam penyampaian dan penjelasan mengenai budaya dan produk-produk budaya Kota Palu melalui kunjungan kebudayaan, pementasan tarian, ikut serta dalam acara International Day Festival yang di selenggarakan oleh International office Universitas Tadulako, dan mengikuti seminar, yang membuat para mahasiswa asing mendapatkan tambahan pengetahuan tentang budaya di tempat tinggal barunya. Kemampuan menyesuaikan diri dan menjalin hubungan antarbudaya yang baik juga mampu meningkatkan kompetensi dalam berhubungan antarbudaya antara mahasiswa asing dengan sesama mahasiswa asing lainnya, mahasiswa Universitas Tadulako, dan juga para dosen di Universitas Tadulako. Komunikasi antarbudaya memainkan peran dalam proses adaptasi dan penyesuaian diri para mahasiswa asing dengan lingkungan barunya.

Perkembangan hubungan yang mencapai suatu derajat "kepribadian" menjadi proses komunikasi yang meliputi komunikasi antarbudaya sebagai jenis komunikasi yang berperan paling efektif dalam rangka mengatasi dan menanggulangi peristiwa gegar budaya. Proses komunikasi berperan ketika mereka harus memiliki pemahaman diri tentang kebutuhan pribadi untuk berinteraksi, belajar, dan bertahan hidup. Komunikasi antarbudaya yang dibangun dan dijalin lebih banyak melalui interaksi tatap muka dan paling sering dilakukan di dalam kelas dengan teman-teman lain. Interaksi tatap muka biasanya berupa sharing tentang pengalaman, budaya kota atau negara asal para mahasiswa asing, atau pendapat tentang kehidupan dan lingkungan baru.

Proses komunikasi menjadi hal penting untuk mempu mengenal lingkungannya, dan setiap orang memerlukan komunikasi. Proses awal dilalui dengan tahapan mulai mengamati sekitar sebagai bahan pembelajaran dan proses adabtasi kemudian melalui mendengarkan berbagai model dan bentuk 
komunikasi yang digunakan secara rutin oleh lawan bicara dan ekspresi yang ditunjukkan, maka akan tercipta proses memori dan meniru hal-hal yang mampu dimanfaatkan dalam proses interaksi saat berkomunikasi. Proses meniru juga bukan menjadi hal mudah di lakukan karena proses budaya dan nilai yang berbeda dari masing-masing individu. Konvergensi disini berfungsi untuk menyamakan aksen yang dipakai agar terlihat sama dengan orang disekitarnya dan dapat beradaptasi dengan baik dan terlihat berbeda dari aksen yang biasanya dipakai mahasiswa asing.

Pemanfaatan teknologi juga membuka kesempatan bagi terjalinnya hubungan komunikasi antarbudaya. memunculkan jalinan komunikasi antarbudaya berupa percakapan pribadi yang berfokus utama pada peningkatan kemampuan berbahasa Indonesia, pencarian informasi tentang suatu peristiwa atau susunan aturan kehidupan sosial, dan konsultasi tentang urusan akademik.

Konvergensi dan divergensi terjadi ketika mahasiswa asing dan temantemannya baik yang dikampus maupun di asrama tempat tinggal saling berkomunikasi. Berawal dari komunikasi tersebut, bisa terlihat apakah mahasiswa asing tersebut menggunakan konvergensi atau divergensi. Konvergensi akan terlihat jika antara mahasiswa asing dan teman-temannya yang saling berkomunikasi, teman-teman mahasiswa asing tersebut meniru cara bicra ataupun gerakan yang dilakukan mahasiswa asing. Hal itu terjadi ketika mereka sedang berbincang santai.

Menurut teori akomodasi, divergensi lebih sering terlihat dibandingkan dengan konvergensi. Tidak begitu yang ditemukan dilapangan, bahwa divergensi lebih terlihat dibanding konvergensi. Konvergensi lebih terlihat dibandingkan divergensi karena informan ingin memperlihatkan kepada orang-orang disekitarnya bahwa mereka juga bisa mengubah aksen kental dari negara mereka, menjadi gaya bicara orang-orang disekitar mereka yang terdengar umum. Terkadang, para informan melakukan divergensi dan konvergensi disaat yang berbeda. Seperti, saat informan bersama dengan teman-teman yang 
berbeda negara, informan cenderung mengubah aksen atau cara bicaranya untuk menyamakan dengan gaya bicara seperti teman-teman disekitarnya. Sedangkan saat informan berada dilingkungan asrama mereka yang terdapat teman-teman dari negara yang sama dengan mereka, mereka lebih nyaman menggunakan aksen ataupun bahasa dari negara mereka sendiri.

Teori akomodasi dapat memiliki peran penting dalam komunikasi karena dapat memperkuat identitas sosial dalam penyatuan, namun dapat pula memperkuat perbedaan dan pemisahan. Konvergensi memang lebih sering terjadi antara informan dan teman informan. Tetapi, jika konvergensi terlalu berlebihan, tak jarang membuat para informan seperti sedang diolok-olok oleh teman-teman mereka sendiri. Khususnya jika meniru sesuatu yang tidak disukai oleh informan yang dapat menimbulkan konflik diantara mereka. Selain konvergensi dan divergensi yang dapat dilihat dari para informan dan teman informan saat sedang berkomunikasi, secara tak sadar ada pola interaksi yang dilakukan baik itu dilakukan oleh informan ataupun teman informan. Pola interaksi yang peneliti maksud disini adalah polaa interaksi yang sering dikenal dengan singkatan RED atau requirements (kebutuhan), expectation (harapan), desires (keinginan). Komunikasi merupakan kebutuhan untuk saling berinteraksi antara satu sama lainnya. Tanpa adanya komunikasi, para informan dan orangorang disekitarnya tidak akan saling mengenal, kemudian para informan memiliki harapan untuk dapat saling mengenal, mengetahui dan memahami apa hasil dari komunikasi tersebut.

Setelah adanya komunikasi yang terjadi sebagai kebutuhan untuk saling berinteraksi dan adanya harapan untuk saling mengenal, timbullah keinginan untuk mengenal lebih baik lagi. Komunikasi akan selalu terjalin antara satu orang dengan orang lain, tanpa mengenal ras, agama, etnik dan lain sebagainya. Komunikasi tak akan pernah lepas dari kehidupan sosial manusia. Komunikasi tersebut kemudian memmbuat para informan belajar apa dan bagaimana hidup di lingkungan baru. Belajar mengenal budaya baru melalui proses komunikasi, 
karena perbedaan budaya, para informan sering salah mengartikan dan memahami, begitupun sebaliknya. keterampilan memahami kebudayaan lain sangat perlu dilakukan agar kita mampu menjalin komunikasi yang efektif. Dengan komunikasi yang efektif akan memudahkan kita bersosialisasi dengan pola nilai kebudayaan yang baru. Apalagi Indonesia merupakan negara kepulauan yang mempunyai ragam adat istiadat, bahasa, dan kebiasaan. Sehingga goncangan kebudayaan atau cultural shock dapat kita minimalisir dan yang paling penting untuk menghindari adanya bentrokan dan permusuhan karena adanya mis komunikasi antar kelompok yang satu dengan yang lainnya.

Komunikasi antarbudaya merupakan komunikasi yang terjadi antara dua kebudayaan yang berbeda, dalam hal ini seperti yang terjadi pada mahasiswa asing saat mengikuti program pertukaran mahasiswa ke Indonesia, dalam hal ini bertemu dengan warga Indonesia yang berbeda budaya dengan mereka. Mahasiswa asing yang di maksud adalah pelajar yang menempuh pendidikan diluar negeri di Universitas Tadulako. Gegar Budaya merupakan keadaan psikologis yang dialami oleh mahasiswa asing saat memasuki kebudayaan baru yang berbeda dari kebudayaan yang dia miliki. Terdapat empat tingkatan gegar budaya (culture shock) yaitu: Fase Opsimistik (Optimistic Phase, berisi kegembiraan, rasa penuh harapan, dan euforia sebagai antisipasi bagi mahasiswa asing yang memasuki budaya baru sebelum mengalami gegar budaya. Pada fase ini mahasiswa asing akan merasa bahagia setibanya di negara yang baru, apalagi negara yang belum pernah dikunjungi sebelumnya. Seseorang cenderung memiliki harapan-harapan yang besar pada saat baru bertemu dengan kebudayaan baru dan orang-orang baru. Fase masalah kultural (Cultural Problems), yaitu kesulitan bahasa, kehidupan sosial yang baru, sekolah baru, dan lain-lain. Fase ini biasanya ditandai dengan rasa kecewa, ketidakpuasan dan segala sesuatunya mengerikan. Saat mahasiswa asing memasuki kebudayaan baru maka mereka mengalami reaksi negatif terhadap perubahan dan penyesuaian diri terhadap lingkungan budaya yang baru. Fase Kesembuhan 
(Recovery Phase), fase ketiga dimana individu mulai mengerti dan memahami budaya barunya. Pada fase ini krisis dapat dipecahkan jika sudah menguasai bahasa pada budaya baru, dengan ini mahasiswa asing sudah bisa membuka jalan ke lingkungan yang baru. Fase Penyesuaian (Adjustment Phase), mahasiswa asing mulai mengerti dan memahami nilai-nilai budaya, pola komunikasi, dan kemampuan untuk hidup dalam dua budaya yang berbeda. Biasanya juga disertai dengan rasa puas dan menikmati.

\section{Simpulan}

Mahasiswa asing yang berkuliah di Universitas Tadulako mengakui pernah mengalami gegar budaya atau cultural shock dengan melewati empat fase yaitu: fase opsimistik (optimistic phase), fase masalah kultural (cultural problems), fase kesembuhan (recovery phase), dan fase penyesuaian (adjustment phase). Dari ke empat bentuk tingkatan gegar budaya tersebut fase yang paling berpengaruh dalam proses komunikasi yang meliputi komunikasi antarbudaya dalam bentukbentuk gegar budaya yang dialami oleh mahasiswa asing di Universitas Tadulako yaitu fase masalah kultural (cultural problems/ culture shock) adalah bahasa, makanan, lingkungan (meliputi cuaca, tempat tinggal, dan akademik), karakteristik masyarakat Kota Palu, agama, dan budaya Indonesia.

Komunikasi antarbudaya sangat berperan penting dalam mengatasi mis komunikasi antar mahasiswa asing dan mahasiwa Universitas Tadulako, karena melalui komunikasi dapat terjalin keakraban antar sesama mahasiswa asing dan mahasiswa Universitas Tadulako, sehingga memudahkan kedua budaya ini dapat saling memahami dan menghargai dengan adanya perbedaan budaya tersebut, dengan demikian keakraban mulai terbentuk yaitu seperti kesadaran untuk membuka diri lebih besar daripada sebelumnya, sehingga masing-masing baik antar sesama mahasiswa asing maupun mahasiswa Universitas Tadulako dapat mempelajari lawan bicara dan mencari solusi agar mampu berkomunikasi lebih 
efektif dan tahu bagaimana harus bertindak untuk menghindari terjadinya mis komunikasi.

Kajian terkait proses komunikasi dalam lingkup komunikasi lintas budaya dilihat selanjutnya dalah konsep bersikap terbuka dengan menerima lingkungan sosial budaya yang baru disekitarnya, menciptakan interaksi yang efektif dan meluaskan jaringan pertemanan yang baru baik di lingkungan perkuliahan maupun lingkungan tempat tinggal akan membantu menumbuhkan perasaan nyaman pada diri individu sehingga dapat meminimalisir kecemasan yang berkelanjutan yang disebabkan oleh efek culture shock.

\section{Daftar Pustaka}

Abbasian Fahime dan Sharifi Shahla. 2013. The Relationship between Culture Shock and Sociolinguistic Shock: A Case Study of Non-Persian Speaking Learners. DOI: 10.12966/ojssr.09.07.2013

Emzir. 2010. M etode Penelitian Kualitatif: Analisis Data. Jakarta: Raja Grafindo Hadawiah. (2019). Fenomena (Gegar Budaya) Pada Mahasiswa Perantauan Di Universitas M uslim Indonesia. In AI-M UNZIR (Vol. 12, Issue 1).

https://ejournal.iainkendari.ac.id/index.php/al-munzir/article/view/1310 Kusherdyana, 2011 Pemahaman Lintas Budaya dalam Konteks Pariwisata dan Hospitalisasi Alfabeta. Bandung

Liliweri, Alo 2001. Gatra-Gatra Komunikasi Antarbudaya. Pustaka Pelajar. Jogjakarta

-------. 2011. Komunikasi Serba Ada dan Serba Makna. Kencana Prenada Media Group : Jakarta

Mulyana, Deddy dan Rakhmat, Jalaluddin 2005 Komunikasi Antar Budaya Panduan Berkomunikasi Dengan Orang-Orang Berbeda Budaya PT. Remaja Rosdakarya Bandung

-------. 2007. Ilmu Komunikasi: Suatu Pengantar. Bandung: Remaja Rosdakarya

Morissan.2013.Teori Komunikasi Individu Hingga Massa, Jakarta: Kencana Prenada M edia Group

Nasrullah Rulli. (2012). Komunikasi Antar Budaya: Di Era Budaya Siber - Rulli

Nasrullah - Google Buku. Kencana.

https:// books.google.co.id/books?hl=id\&lr=\&id=EdbFDwAAQBAJ\&oi=fnd\&p $g=P R 1 \& d q=k o m u n i k a s i+d a n+b u d a y a \&$ ots=CDxouM kW 3f\&sig=B2HP726zOOI gLamGdbK41nHRDLs\&redir_esc $=y \# v=0$ nepage $\& q=k o m u n i k a s i$ dan budaya $\& f$ false

O. Rikastana, T. Rahardjo, L. Rahmiaji, and A. Nugroho, "Pengalaman Akomodasi Komunikasi (Kasus: Interaksi Etnis Jawa dengan Etnis Batak)," Interaksi 
Jurnal Audience: Jurnal Ilmu Komunikasi

Vol 03 No. 02 Tahun 2020

Online, vol. 4, no. 1, Dec. 2015. [Online].

Rahardjo, Turnomo 2005. Menghargai Perbedaan Kultural mindfulness Dalam Komunikasi Antar Etnis. Yogyakarta : Pustaka Pelajar

Samovar, L.A, Richard Porter, dan Edwin McDaniel. 2007. Komunikasi Lintas Budaya Edisi 5 .Jakarta: Salemba Humanika

Yohana Nova \& Yozani Eldapi Ringgo. Akomodasi Komunikasi Antarbudaya Imigran llegal Asal Afganistan Dengan Masyarakat Kota Pekanbaru. 2017. DOI: http://dx.doi.org/10.21107/ilkom.v11i2.3324 